\title{
Toward regional hazard risk assessment: a method to geospatially inventory critical coastal infrastructure applied to the Caribbean
}

\author{
Austin Becker ${ }^{1 *}$ (D), Noah Hallisey ${ }^{1}$ and Gerald Bove ${ }^{2}$
}

\begin{abstract}
Hurricanes and sea level rise pose significant threats to infrastructure and critical services (e.g., air and sea travel, water treatment), and can hinder sustainable development of major economic sectors (e.g., tourism, agriculture, and international commerce). Planning for a disaster-resilient future requires high-resolution, standardized data. However, few standardized approaches exist for identifying, inventorying, and quantifying infrastructure lands at risk from natural hazards. This research presents a cost effective, standardized and replicable method to geospatially inventory critical coastal infrastructure land use and components, for use in risk assessments or other regional analyses. While traditional approaches to geospatial inventorying rely on remote sensing or techniques, such as object-based image analysis (OBIA) to estimate land use, the current approach utilizes widely available satellite imagery and a "standard operating procedure" that guides individual mappers through the process, ensuring replicability and confidence. As a pilot study to develop an approach that can be replicated for other regions, this manuscript focuses on the Caribbean. Small islands rely heavily on a small number of critical coastal infrastructure (airports, seaports, power plants, water and wastewater treatment facilities) and climate related hazards threaten sustainable development and economic growth. The Caribbean is a large and diverse area, and gaps exist between countries in the resources required for planning but much of the region lacks a comprehensive inventory of the land, infrastructure, and assets at risk. Identifying and prioritizing infrastructure at risk is the first step towards preserving the region's economy and planning for a disaster resilient future. This manuscript uses high resolution satellite imagery to identify and geo-spatially classify critical infrastructure land area and assets, such as structures, equipment, and impervious surfaces. We identified 386 critical coastal infrastructure facilities across 28 Caribbean nations/territories, with over 19,000 ha of coastal land dedicated to critical infrastructure. The approach establishes a new standard for the creation of geospatial data to assess land use change, risk, and other research questions suitable for the regional scale, but with sufficient resolution such that individual facilities can utilize the data for local-scale analysis.
\end{abstract}

Keywords: Critical infrastructure, Geospatial data development, Risk assessment, Caribbean, Regional assessments, Heads-up digitizing, Land use and land cover

\footnotetext{
*Correspondence: abecker@uri.edu

'Department of Marine Affairs, University of Rhode Island, 1 Greenhouse Rd., Kingston, Rhode Island 02881, USA

Full list of author information is available at the end of the article
}

\section{Springer Open}

( ) The Author(s). 2021 Open Access This article is licensed under a Creative Commons Attribution 4.0 International License, which permits use, sharing, adaptation, distribution and reproduction in any medium or format, as long as you give appropriate credit to the original author(s) and the source, provide a link to the Creative Commons licence, and indicate if changes were made. The images or other third party material in this article are included in the article's Creative Commons licence, unless indicated otherwise in a credit line to the material. If material is not included in the article's Creative Commons licence and your intended use is not permitted by statutory regulation or exceeds the permitted use, you will need to obtain permission directly from the copyright holder. To view a copy of this licence, visit http://creativecommons.org/licenses/by/4.0/. 


\section{Highlights}

- Created a cost effective, standardized, and replicable method to geospatially inventory critical coastal infrastructure land use

- The approach improves on other geospatial data collection approaches where land use data is required for conducting regional assessments of storm risk, climate risk, or economic projections

- Pilot study of Caribbean shows 19,000 ha of coastal land dedicated to critical infrastructure

- Developed an inventory of Caribbean critical infrastructure assets (buildings, paved surfaces, industrial structures, etc.) at a regional scale

- The results of this study can be used to track land use change over time and provide guidance for urban planning in coastal regions with limited land area for development

\section{Introduction}

Planning for a disaster-resilient future requires highresolution, standardized data on a regional scale in order to properly assess risk. However, few standardized approaches exist for identifying, inventorying, and quantifying regional land and infrastructure at risk from natural hazards. Hurricanes and sea level rise pose a significant threat to infrastructure and critical services that were built in harm's way, such as water telecommunications, energy, and international commerce. These threats hinder sustainable development of major economic sectors, such as tourism, agriculture, and international commerce. They also pose significant threats to fragile coastal ecosystems, as infrastructure-related disasters can result in the release of hazardous materials [1-3]. While individual islands, nations, or local governments may already possess such datasets for their specific location, access to and consistency between such datasets remains a significant challenge for researchers wishing to conduct regional studies $[4,5]$. Due to the varying nature of coastal infrastructure, this last piece presents unique challenges. This research develops a standardized and replicable method to geospatially inventory critical coastal infrastructure land use and components. The resulting data can be used for natural hazard vulnerability assessment, tracking land use change over time, as well as other applications, on a regional scale.

As a pilot to develop an approach that can be replicated for other regions, this manuscript focuses on the 28 island nations and territories in the Caribbean. Island economies such as those in the Caribbean rely on their critical coastal infrastructure, such as airports, seaports, power plants, water and wastewater treatment facilities. Due to its geographic location and topography, the Caribbean is one of the most natural-disaster prone regions worldwide [6] and climate related hazards threaten sustainable development and economic growth $[7,8]$. While climate related hazards pose a significant threat to critical infrastructure, like many areas around the world, the region lacks a comprehensive inventory of the land, infrastructure, and assets at risk. Identifying and prioritizing infrastructure at risk is a first step towards preserving the region's economy and planning for a disaster resilient future $[9,10]$.

Using the most up-to-date high-resolution satellite imagery, this manuscript employs heads-up digitizing, a method of manually tracing geographic features using aerial imagery, to identify and geo-spatially classify critical infrastructure land area and assets, such as buildings, industrial structures, and impervious surfaces. This approach establishes a standard for the creation of geospatial data that can be used to assess land use change, hazard risk, and other research questions suitable for the regional scale, but with sufficient resolution such that individual facilities can utilize the data for local-scale analysis.

This paper begins with a discussion of various approaches to the creation and classification of geospatial data that could be used for analyzing environmental risks and answering other questions about intra-regional challenges. It then provides our justification for focusing on the Caribbean as a pilot study to develop a new methodology for creating regional land use inventories. Next, the methodology and "standard operating procedure" is laid out in detail. We tested our approach in a validation exercise to explore how well our methodology worked when followed by different mappers. The results section summarizes the total coastal land area in the Caribbean that is devoted to critical coastal infrastructure. Finally, the discussion section addresses the implications, shortcomings, and next steps for this work.

\section{Background - geospatial data and its implications for storm assessments and land use planning}

Hurricanes and sea level rise pose a significant threat to infrastructure and critical services and can hinder sustainable development of major economic sectors [11]. Planning for a disaster-resilient future requires highresolution, standardized data on a regional scale [12]. For example, ocean scientists rely on high-resolution bathymetry and elevation data sets to develop models of sea level rise, storm surge, waves, and riverine flooding [13]. The impacts of these hazards on society and the environment, however, depend on what lies in harm's way. While advances in regional storm modeling have resulted in more reliable projections of climate hazards, few standardized approaches exist for identifying, inventorying, and quantifying regional land and infrastructure at risk from episodic coastal flooding and/or chronic sea level rise. While there are numerous methods to assess 
vulnerability and risk at the micro and meso-scale, critical infrastructure are not typically included [14] and when they are, risk is typically assessed only to one $\mathrm{XY}$ coordinate (a "point") as opposed to the land occupied by the entire facility (See e.g., [12, 15, 16]). Developing countries are expected to experience the greatest impacts of climate change to their economies and livelihoods $[17,18]$ and limited access to resources constrains their ability to adapt in the face of more frequent storm events and a changing climate [17]. While a vast amount of geospatial data has been created over the last several decades at almost every scale, there remains a dearth of high-resolution land use classification data at the regional scale that can be used for environmental risk and vulnerability assessments of coastal infrastructure. The rest of this section describes some of the techniques to create and classify data.

\section{Land use and land cover data}

Vegetated, non-vegetated, and man-made features are ubiquitous throughout the Earth's landscape. High spatial and temporal resolution satellite imagery have improved researchers' ability to classify land use and land cover (LULC). Most notably, the Landsat satellite program (www.nasa.gov/mission_pages/landsat/) sparked a surge in the development of remote sensing techniques to comprehensively characterize, quantify, and monitor the Earth's surface $[19,20]$. Land cover characterizes the physical materials covering the landscape, such as forest, grass, or open water while land use represents the function land serves, such as commercial, residential, or agricultural [21]. LULC information play an important role for addressing environmental issues, such as monitoring LULC change [22-24] and modeling the impacts of urbanization $[25,26]$. Seto et al. [27] estimated that global urban land cover will increase by 1.2 million $\mathrm{km}^{2}$ by 2030 , a $185 \%$ increase from the year 2000. Increased urbanization will likely threaten biodiversity, result in the loss of fertile crop land [28] and exacerbate the impacts of climate change [29]. While only $1.8 \%$ of world land, excluding Antarctica, is located in the low elevation coastal zone (LECZ), a full $10 \%$ of the world population lived in this zone in 2010 . Density is expected to increase from 288 inhabitants $/ \mathrm{km}^{2}$ to 455 inhabitants $/ \mathrm{km}^{2}$ by 2100 [30]. High concentrations of people, industry, assets, and infrastructure in urban areas, like major cities located in the LECZ, are at the greatest risk to the effects of climate change and natural disasters [31].

\section{Automated and machine learning LULC classification}

Identifying, extracting, and classifying detailed and nuanced features in urban areas requires high spatial resolution (HSR) satellite imagery [32, 33]. However, HSR is not available in all regions of the world and lower resolution imagery lacks the level of detail necessary to extract detailed urban LULC [34]. Automated classification techniques like object-based image analysis (OBIA), a method that groups pixels into objects with similar spectral characteristics, are promising approaches for higher accuracy land use and land cover classification $[35,36]$. However, OBIA is not effective for classifying the urban landscape [37]. OBIA relies on the segmentation of pixels into groups, limiting the ability to differentiate objects constructed of materials with similar spectral characteristics, such as impervious surfaces and buildings [35]. Pixel based urban land-use classification has a similar problem. Even with high resolution satellite imagery, the heterogeneity of the landscape is too complex for accurate classification. Machine learning techniques, such as Convolution Neural Networks (CNN) and Random Forest (RF), have also been applied to improve accuracy of automated land cover classification $[38,39]$. However, these methods present similar limitations of classifying urban land-cover, such as misidentifying features with similar spectral characterizes and requiring large amounts of training data for high accuracy classification, in addition to requiring a reasonably high skill set to properly implement [38-40].

\section{Open street maps}

Open Street Maps (OSM) is a web-based platform for crowd-sourcing of publicly available spatial data generated by users all over the world, commonly referred to as volunteered geographic information [41]. OSM collected data has been integrated in a number of applications including LULC mapping [42] and urban planning [43]. Due to the high cost of collecting and maintaining geo-spatial data, OSM provides a free alternative mapping service for the aggregation and distribution of spatial data. While OSM data is extensive, particularly in densely constructed urban areas, the contribution of individuals lacking a formal training in geographic information systems can lead to the generation of data that is of lower quality and accuracy compared to authoritative databases generated by local, state, and national agencies $[44,45]$. For example, a comparison of OSM building footprint data to an authoritative reference dataset in Munich, Germany identified that while OSM derived geospatial data had a high area completeness, many of the buildings included in the authoritative dataset were not mapped in OSM dataset [4]. In addition, buildings in dense urban areas were grouped together and lacked rich building attribute information. Other studies comparing OSM derived data to authoritative databases have identified similar limitations, such as a lack of detailed attributes and lower accuracy and completeness in rural areas [45]. 


\section{Heads-up digitizing}

Heads-up digitizing refers to a method of manually transposing information from an image into points, lines, and polygons in a digital file typically called a shapefile. The user looks at an image, such as an orthophotograph, on a computer screen and traces the features of interest into a new digital file. The technique is more labor intensive than automated classification used in remote sensing, but is still used for many applications, especially when data are not conducive to an algorithm for making classification decisions. Many digital maps currently in wide use were created using this process.

\section{Limitation of risk/vulnerability assessment}

The frequency of coastal flooding due sea level rise is expected to double in the coming decades [46]. High accuracy spatial resolution Light Detecting and Ranging (LIDAR) and Digital Elevation Models (DEMS) have allowed for greater detailed flood risk mapping and vulnerability assessments $[47,48]$. However, varying DEM sources and their associated elevation error can impact the ability to predict coastal flooding and its risk [49]. For example, a study comparing LiDAR derived DEMs to publicly available DEMs concluded that publicly available DEMs did not meet the level of accuracy necessary for flood risk assessment, particularly at a greater spatial scale [50]. Risk and vulnerability assessments are used in coastal regions throughout the world to aid in understanding the impacts of major storm events and future sea level rise scenarios [51-53]. High-resolution modeling, such as the Advanced Circulation Model for Shelves, Seas, and Estuaries (ADCIRC), has allowed for a comprehensive and informative assessment of flooding risk $[54,55]$. Increasing development in coastal regions coupled with more frequent and intense extreme weather events has increased exposure and vulnerability to people, assets, and infrastructure [56].

\section{Methods}

The approach used in this manuscript establishes a standard for the creation of geospatial data that can be used to assess land use change, risk, and other research questions suitable for the regional scale, but, with sufficient resolution such that individual facilities can utilize the data for local-scale analysis. This manuscript builds on work that developed the first geospatial inventory of Rhode Island's (USA) commercial ports and harbors [57]. It introduces a "standard operation procedure" (SOP) to employ a heads-up digitizing approach to identify and geo-spatially classify critical infrastructure, their land area and assets, such as buildings, industrial structures and impervious surfaces. Serving as a guide for a reliable and repeatable approach for the creation of geospatial data for critical infrastructure using heads-up digitizing, the SOP consists of decision-making criteria mappers can use to determine critical infrastructure facility land use boundaries and key features to digitize, as well as outlining the digitizing procedure and a number of "what-if" scenarios that a mapper might encounter.

\section{Caribbean as a case study}

In this paper, we use the Caribbean region as a case study (Fig. 1 and Table 1). This collection of island nations faces a unique set of economic, social, and environmental challenges. Island economies such as those in the Caribbean heavily rely on critical infrastructure and the services they provide. With much of the region's infrastructure located in the coastal zone, the impacts of climate change are expected to disrupt the regions tourism economy and commerce [58]. The Inter-American Development Bank projects that the Caribbean could face climate-related losses in excess of $\$ 22$ billion annually by 2050 [59]. Due to the relative isolation of the islands and lack of natural resources, airports and seaportsare important links for socio-economic development and connectivity between islands in the region and the global economy. In addition, seaports and airports are lifelines for goods such as energy resources, food, potable water (and nearly all of the other imported goods that are part of modern life). Energy facilities and water treatment provide electricity and potable water, necessities that modern day cities cannot do without. Under current climate change projections plus continued development in the coastal zone which is often improperly regulated, critical infrastructure in the region may face more frequent flooding and operational disruptions as early as the 2030s [60]. While climate related hazards pose a significant threat to critical infrastructure, like many areas around the world, the region lacks a comprehensive inventory of the land, infrastructure, and assets at risks.

In this pilot study, mapped infrastructure meets the following criteria: 1) it is an airport, seaport, water treatment, or energy facility, 2) it is located within $1 \mathrm{~km}$ of the coastline, and 3) it must be currently in use All facilities were also cross-referenced through Google searches.

\section{Existing databases of infrastructure}

In order to create the inventory, we first searched for existing datasets of infrastructure. Limited critical infrastructure databases exist in this region and throughout the world. Those that do exist are almost exclusively "point datasets," meaning that each facility is identified as one XY coordinate, with information provided about aspects of that facility, such as depth of water if a seaport or airport code if an airport. The single XY point coordinate associated with each facility may or may not be geographically located on the facility itself, though it usually is in close proximity. Our manuscript recognizes 


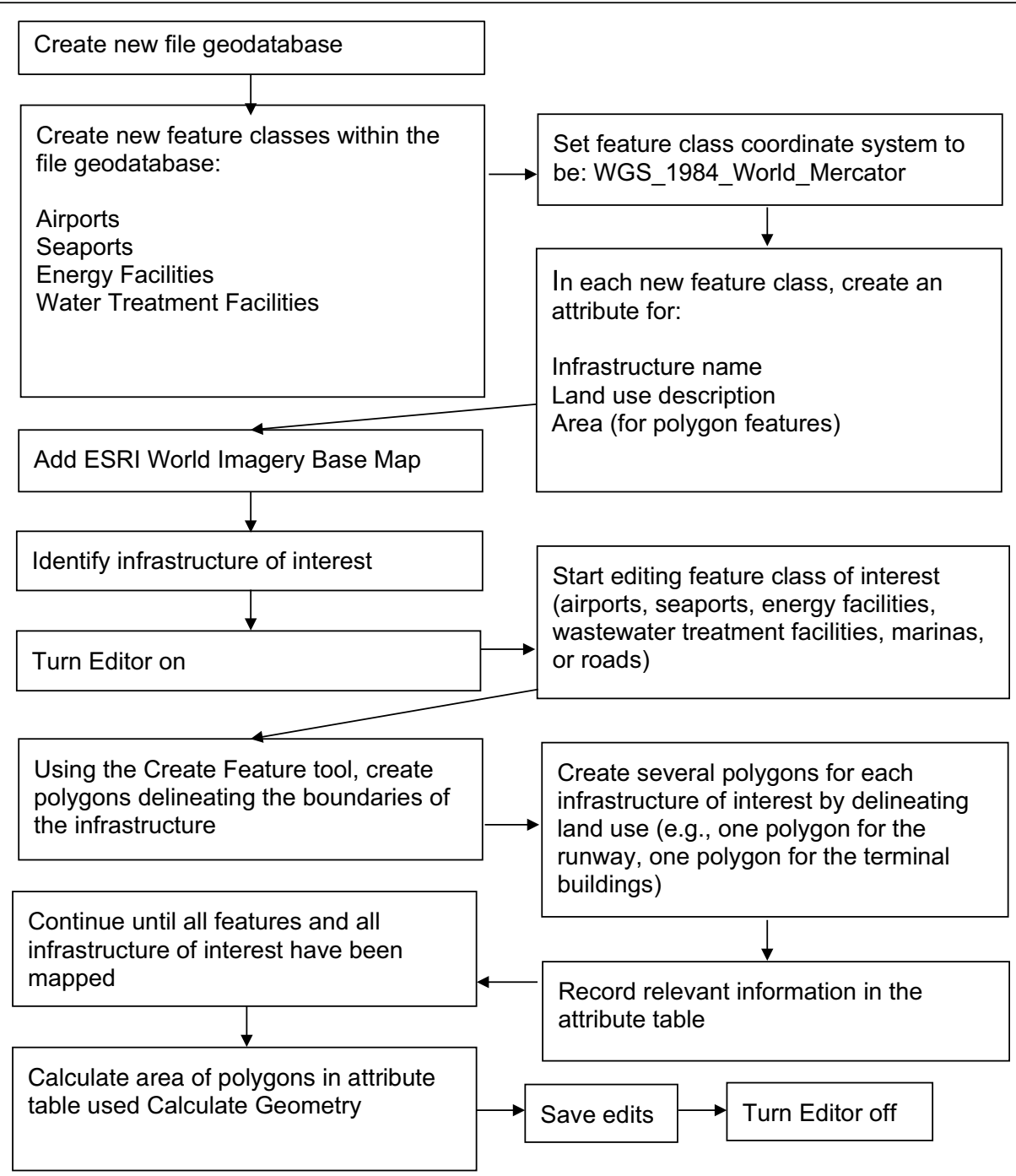

Fig. 1 Map of critical coastal infrastructure facilities in study area

the need for "polygon" datasets, which allow for a more nuanced analysis of land use and risk.

That said, we relied upon several worldwide databases (Table 2) and online sources to first identify and inventory critical infrastructure points. Seaports were identified from the World Port Index [61] prepared by the National Geospatial-Intelligence Agency and Countries with ports in the Caribbean prepared by World Port Source [62]. These databases include port name, latitude and longitude, and port characteristics (e.g., facilities and services offered). Seaport types within our database included cruise ports, container ports, oil terminals, and general purpose ports. Airports were identified from OpenFlights Airport Database [63] and World Airport Database [64]. These databases included airport name, longitude and latitude, and airport ID. We were unable to locate regional databases for water and wastewater treatment facilities and energy facilities. Instead, both facility types were identified through a google search using terms such as "Caribbean Power Plants" of "Caribbean Water Treatment Facilities". Energy facilities were categorized by their fuel source, and included power plants (natural gas, coal, etc.), oil refineries, nuclear power plants, and solar and wind farms. Water and wastewater treatment facilities included water treatment facilities, desalination plants, and wastewater treatment facilities. We aggregated critical infrastructure facilitates identified from existing databases and google searches into an individual inventory for each facility type in a point shapefile containing facility name, facility type, location, and coordinates.

\section{Satellite imagery}

In order to create polygons for land uses and facility assets, we relied on satellite imagery to recognize key features. Base imagery used to digitize critical infrastructure 
Table 1 Study area characteristics

\begin{tabular}{|c|c|c|c|c|c|c|c|}
\hline Country & $\begin{array}{l}\text { Total Land Area } \\
\left(\mathrm{km}^{2}\right)^{\mathrm{a}}\end{array}$ & $\begin{array}{l}\text { Population } \\
(2020)^{a, b}\end{array}$ & $\begin{array}{l}\text { GDP } \\
\text { (US\$M) } \\
a, b\end{array}$ & $\begin{array}{l}\text { \# of } \\
\text { Airports }^{\mathrm{a}}\end{array}$ & $\begin{array}{l}\text { \# of } \\
\text { Seaports }\end{array}$ & $\begin{array}{l}\text { \# of Energy } \\
\text { Facilities }^{\mathrm{a}}\end{array}$ & $\begin{array}{l}\text { \# of Water Treatment } \\
\text { Facilities }^{\mathrm{a}}\end{array}$ \\
\hline Anguilla $a^{5, u, o e}$ & 91 & 18,090 & 175.4 & 1 & 1 & 1 & 1 \\
\hline $\begin{array}{l}\text { Antigua and } \\
\text { Barbuda }{ }^{\text {s,u, oe }}\end{array}$ & 442.6 & 98,179 & 1.5 & 2 & 1 & 3 & 1 \\
\hline Aruba $^{5}$ & 180 & 119,428 & 2700 & 1 & 4 & 3 & 3 \\
\hline The Bahamas ${ }^{\mathrm{s}, \mathrm{u}}$ & 10,010 & 337,721 & 12,060 & 9 & 8 & 3 & 0 \\
\hline Barbados $^{\mathrm{s}, \mathrm{u}}$ & 430 & 294,560 & 4990 & 1 & 1 & 3 & 3 \\
\hline Bermuda $a^{\mathrm{s}}$ & 54 & 71,750 & 6127 & 1 & 4 & 2 & 2 \\
\hline Bonaire & 228 & 25,897 & 428 & 1 & 2 & 2 & 1 \\
\hline $\begin{array}{l}\text { British Virgin } \\
\text { Islands s,oe }\end{array}$ & 151 & 37,381 & 1028 & 2 & 1 & 1 & 0 \\
\hline Cayman Islands $^{5}$ & 264 & 61,944 & 2250 & 3 & 2 & 2 & 5 \\
\hline $\mathrm{Cuba}^{\mathrm{s,u}}$ & 110,860 & $11,059,062$ & 93,790 & 6 & 31 & 12 & 0 \\
\hline Curaçao ${ }^{5}$ & 444 & 151,345 & 5600 & 1 & 4 & 4 & 1 \\
\hline Dominica $^{\mathrm{s}, \mathrm{u}, \mathrm{oe}}$ & 751 & 74,243 & 557 & 2 & 3 & 2 & 1 \\
\hline Dominican Republic ${ }^{\text {s,u }}$ & 48,760 & $10,499,707$ & 76,090 & 7 & 16 & 8 & 0 \\
\hline Grenada $a^{\mathrm{s}, \mathrm{u}, \mathrm{oe}}$ & 344 & 113,094 & 1119 & 2 & 1 & 1 & 0 \\
\hline Guadeloupe $^{\text {s,oe }}$ & 1628 & 400,139 & - & 2 & 4 & 4 & 2 \\
\hline Haiti ${ }^{\mathrm{s}, \mathrm{u}}$ & 27,750 & $11,067,777$ & 8608 & 2 & 10 & 3 & 1 \\
\hline Jamaica, & 10,991 & $2,808,570$ & 14,770 & 5 & 12 & 7 & 3 \\
\hline Martinique $\mathrm{e}^{\mathrm{s}, \mathrm{e}}$ & 1128 & 376,400 & - & 1 & 2 & 3 & 3 \\
\hline Montserrat ${ }^{\mathrm{s}, \mathrm{oe}}$ & 102 & 5373 & 167.4 & 0 & 1 & 1 & 0 \\
\hline Puerto Rico ${ }^{5}$ & 8959 & $3,189,068$ & 104,200 & 5 & 18 & 13 & 8 \\
\hline Saint Lucia ${ }^{\mathrm{s}, \mathrm{u}}$ & 606 & 166,487 & 1686 & 1 & 3 & 0 & 0 \\
\hline Saint Martin ${ }^{5}$ & 54.4 & 32,556 & 561.5 & 2 & 4 & 3 & 1 \\
\hline Sint Eustatius ${ }^{5}$ & 21 & 3140 & 108 & 1 & 1 & 1 & 0 \\
\hline St. Kitts and Nevis ${ }^{\mathrm{s}, \mathrm{oe}}$ & 261 & 53,821 & 964 & 2 & 2 & 3 & 1 \\
\hline $\begin{array}{l}\text { St. Vincent \& } \\
\text { Grenadines }{ }^{s, u, o e}\end{array}$ & 389 & 101,390 & 785 & 5 & 6 & 1 & 0 \\
\hline Trinidad \& Tobago $\mathrm{o}^{\mathrm{s}, \mathrm{u}}$ & 5128 & $1,208,789$ & 22,780 & 1 & 10 & 4 & 3 \\
\hline $\begin{array}{l}\text { Turks and Caicos } \\
\text { Island }^{5}\end{array}$ & 948 & 55,926 & 632 & 3 & 3 & 2 & 1 \\
\hline U.S. Virgin Islands ${ }^{5}$ & 346 & 106,235 & 5182 & 2 & 15 & 6 & 6 \\
\hline
\end{tabular}

${ }^{a}$ Facilities within $1 \mathrm{~km}$ of the coastline and currently active; ${ }^{\mathrm{b}}$ The WorldFactBook (https://www.cia.gov/library/publications/resources/the-world-factbook/); ${ }^{\mathrm{c}}$ Statista

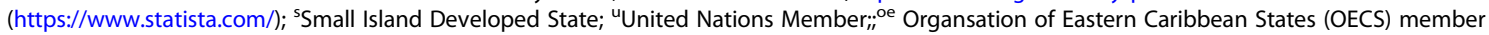

boundaries and assets needs to be up-to-date and high resolution. Availability of recent high-resolution satellite imagery varies depending on geographic location. While sources for high-resolution imagery, such as Planet, Inc. (https://www.planet.com/) and Satellite Imaging Corp (https://www.satimagingcorp.com/), are available for some regions throughout the world, acquiring regional scale imagery can be costly. Publicly available imagery, such as ESRI World Imagery, is a cost-effective source of high-resolution imagery for detailed feature extraction. Last updated in 2020, ESRI World Imagery provides 1 meter or better satellite and aerial images worldwide, including $15 \mathrm{~m}$ Terra Color Imagery at small and mid-scales $(\sim 1: 591 \mathrm{M}$ down to $\sim 1: 72 \mathrm{k})$ and $2.5 \mathrm{~m}$ SPOT Imagery ( 1:288 $\mathrm{k}$ to $1: 72 \mathrm{k})$ and typically captured within the last three to 5 years. To be considered suitable for this project, imagery used must have been the most up-to-date and captured after 2010. Imagery resolution ranged between $0.31-0.50 \mathrm{~m}$ with the date of imagery ranging from $03 / 09 / 2011$ to $12 / 10 / 2019$. We defined an imagery scale range of 1:1000-1:8000, allowing for the digitization of larger features and parcel boundaries while ensuring that smaller features could be captured accurately. In some instances, imagery was either 
Table 2 Databases used to locate critical infrastructure facilities

\begin{tabular}{|c|c|c|c|c|c|}
\hline Facility Type & $\begin{array}{l}\text { Main } \\
\text { Source }\end{array}$ & $\begin{array}{l}\text { Specific } \\
\text { Source }\end{array}$ & URL & Data Type & Description \\
\hline Ports & $\begin{array}{l}\text { World Port } \\
\text { Index }\end{array}$ & $\begin{array}{l}\text { WPI_} \\
\text { Shapefile }\end{array}$ & $\begin{array}{l}\text { https://msi.nga.mil/ } \\
\text { Publications/WPI }\end{array}$ & Shapefile & $\begin{array}{l}\text { Shapefile with points for each terminal. Multiple } \\
\text { terminals per port. }\end{array}$ \\
\hline Ports & $\begin{array}{l}\text { World Port } \\
\text { Source }\end{array}$ & $\begin{array}{l}\text { Countries } \\
\text { with ports in } \\
\text { the } \\
\text { Caribbean }\end{array}$ & $\begin{array}{l}\text { http://www.worldportsource. } \\
\text { com/ports/region.12.php }\end{array}$ & Shapefile & $\begin{array}{l}\text { Breakdown of ports by country. Port icons are coded } \\
\text { by size. }\end{array}$ \\
\hline Airports & $\begin{array}{l}\text { OpenFlights } \\
\text { Airports } \\
\text { Database }\end{array}$ & $\begin{array}{l}\text { OpenFlights } \\
\text { Airport } \\
\text { Database }\end{array}$ & $\begin{array}{l}\text { https://openflights.org/data. } \\
\text { html\#airport }\end{array}$ & $\begin{array}{l}\text { Spreadsheet } \\
\text { File }\end{array}$ & $\begin{array}{l}\text { As of January 2017, the OpenFlights Airports Database } \\
\text { contains over 10,000 airports }\end{array}$ \\
\hline Airports & $\begin{array}{l}\text { World } \\
\text { Airport } \\
\text { Database }\end{array}$ & $\begin{array}{l}\text { World Airport } \\
\text { Database }\end{array}$ & $\begin{array}{l}\text { http://www.world-airport- } \\
\text { database.com/database.html }\end{array}$ & $\begin{array}{l}\text { Spreadsheet } \\
\text { File }\end{array}$ & $\begin{array}{l}\text { One of the largest airport databases in the world with } \\
\text { information on } 33,539 \text { airports in } 228 \text { countries. A } \\
\text { satellite map of more than } 31,000 \text { airports is also } \\
\text { available. }\end{array}$ \\
\hline $\begin{array}{l}\text { Water and } \\
\text { Wastewater } \\
\text { Treatment } \\
\text { Facilities }\end{array}$ & Google & Google Maps & $\begin{array}{l}\text { https://www.google.com/ } \\
\text { maps }\end{array}$ & N/A & $\begin{array}{l}\text { Key Search Terms: Water treatment plant; Wastewater } \\
\text { Treatment Plant; Sewage Treatment Plant; Desalination } \\
\text { plant; Water Authority }\end{array}$ \\
\hline $\begin{array}{l}\text { Energy } \\
\text { Facilities }\end{array}$ & Google & Google Maps & $\begin{array}{l}\text { https://www.google.com/ } \\
\text { maps }\end{array}$ & N/A & $\begin{array}{l}\text { Key Search Terms: Power Plant; Power Station; Nuclear } \\
\text { Power Plant; Wind Farm; Solar Farm }\end{array}$ \\
\hline All & ArcGIS & $\begin{array}{l}\text { Basemap - } \\
\text { World } \\
\text { Imagery }\end{array}$ & $\begin{array}{l}\text { https://www.arcgis.com/ } \\
\text { home/item.html?id=10df22 } \\
\text { 79f9684e4a9f6a7f08febac2a9 }\end{array}$ & Orthoimagery & $\begin{array}{l}\text { World Imagery, last updated August 2020, provides } \\
\text { one meter or better satellite and aerial imagery in } \\
\text { many parts of the world and lower resolution satellite } \\
\text { imagery worldwide. The map includes } 15 \mathrm{~m} \text { TerraColor } \\
\text { Imagery at small and mid-scales ( } \sim 1: 591 \mathrm{M} \text { down to } \\
\sim 1: 72 \mathrm{k}) \text { and } 2.5 \mathrm{~m} \text { SPOT Imagery }(\sim 1: 288 \mathrm{k} \text { to } \sim 1: 72 \\
\text { k) for the world. }\end{array}$ \\
\hline All & $\begin{array}{l}\text { Google } \\
\text { Earth }\end{array}$ & Google Earth & $\begin{array}{l}\text { https://support.google.com/ } \\
\text { earth/answer/148094?hl=en }\end{array}$ & Orthoimagery & $\begin{array}{l}\text { Google Earth contains a large collection of imagery, } \\
\text { including satellite, aerial, 3D, Street View, as well as } \\
\text { historical images. Images are collected over time from } \\
\text { providers and platforms. }\end{array}$ \\
\hline
\end{tabular}

of low resolution or had significant cloud cover over a facility. In these situations, we were unable to extract features from the imagery.

\section{Creation of a standard operating procedure (SOP)}

To standardize an approach for geospatially inventorying critical coastal infrastructure, we developed a Standardized Operating Procedure (SOP) for digitizing critical coastal infrastructure in ArcMap (Fig. 3). The SOP lays out clear guidelines and directions for different mappers to develop similar geospatial data. While the methodology developed is specific to ArcMap, it can be easily be adapted for use on any platform or open source application (e.g., QGIS). For each facility type, mappers create a polygon feature class projected using WGS 1984 Web Mercator (Auxiliary Sphere) within a file geodatabase in ArcMap. The digitization process followed these three basic steps (further details may be found in the Additional file 1):

Step 1: The first step in our digitization process was to define the parcel boundary for a facility, which we defined as the entire land area owned by the facility that encompassed all assets owned by the facility. With many of the critical coastal infrastructure located in highly developed areas, determining the facility boundary could be challenging, particularly in regions with lower resolution imagery. To guide boundary delineation, we used linear structures, such as roads and fences surrounding a facility to determine the land area covered by the facility.

Step 2: Next, polygons of key assets for each facility type, such as buildings, liquid bulk storage tanks, and runways were delineated from the imagery. Mappers used the snapping toolbar in ArcMap to prevent adjacent features, such as buildings in close proximity, from overlapping.

Step 3: For each feature digitized, detailed information, such as the feature type, facility name, facility type, location, the date and resolution of the imagery used were recorded in the attribute table. This process was completed for each facility type, and each database was checked for quality assurance and consistency.

Because decisions about boundaries and classifications are subjective to the mapper's perceptions, the SOP describes in detail how decisions should be made regarding drawing lines, classification, and scale. Within the SOP, 
we developed a set of systematic and repeatable procedures, such as defining an imagery scale range for headsup digitizing, to guide a mapper in the creation and classification of uniform polygon features for critical coastal infrastructure (Fig. 2). For each facility type, we outlined a standardized inventory of features to be mapped, such as runways for airports, for the mappers to reference as a guide in making decisions about extracting features from satellite imagery (Fig. 3).

Given the lack of publicly available imagery in certain regions and the geospatial circumstances for some critical infrastructure facilities, such as facilities located in densely constructed urban vs. less developed rural areas, mappers may be confronted with circumstances that complicate the process of heads-up digitizing critical coastal infrastructure. To meet this challenge, we created "what-if" scenarios (see SOP Section 4.1) to augment the set of rules and provide mappers with guidance on how to proceed under different circumstances. For example, the "what ifs" can help the mapper determining a parcel boundary that is not immediately obvious or select the appropriate imagery to use when the imagery and image date changes at different scales.

\section{Results}

Results of this pilot study allow for a macro-level analysis of infrastructure land use in the Caribbean Islands region. In total, we identified 566 critical infrastructure facilities in the Caribbean across the 28 island nation territories. Of that, approximately $65 \%(n=386)$ of the facilities were within $1 \mathrm{~km}$ of the coast and satisfied the requirements as critical coastal infrastructure, thus we included in our analysis. These facilities encompass a total land area of 19,118 ha of land area in the Caribbean (Table 3). This section first describes results for each critical infrastructure category, as well as the results of a validation exercise. It then provides some key findings about the methodological approach itself.

\section{Airports}

Island economies such as those in the Caribbean depend on airports for trade, food, and energy needs. Additionally, a majority of Caribbean Island GDP is directly dependent on tourism, for which airports are a critical component. Airports in the Caribbean are frequently sited along the coast, as coastal land offers large expanses of flat space and an approach by sea that makes takeoff and landing easier

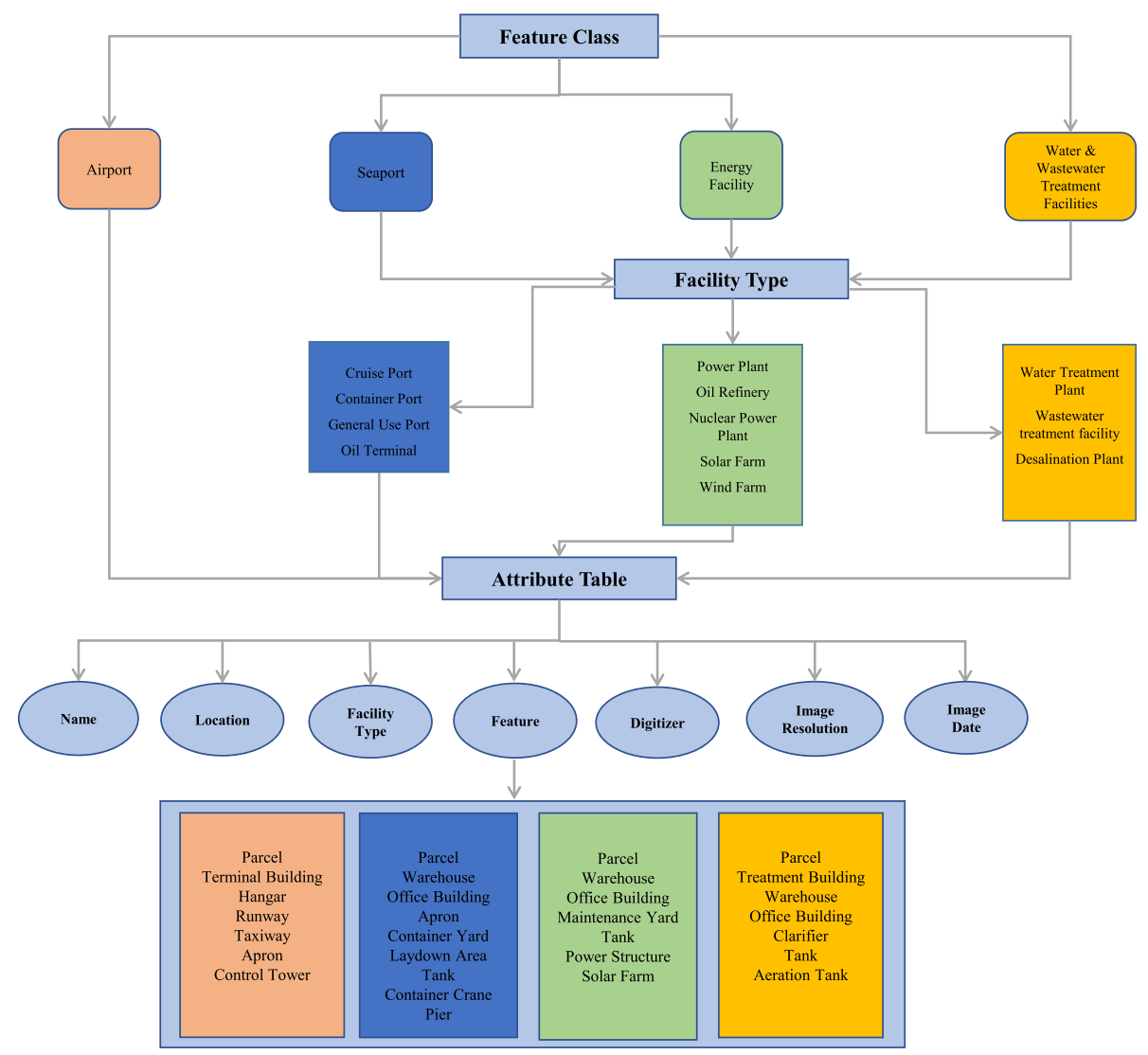

Fig. 2 Decision making process for mapping critical coastal infrastructure (See SOP in Additional file 1 for full details) 

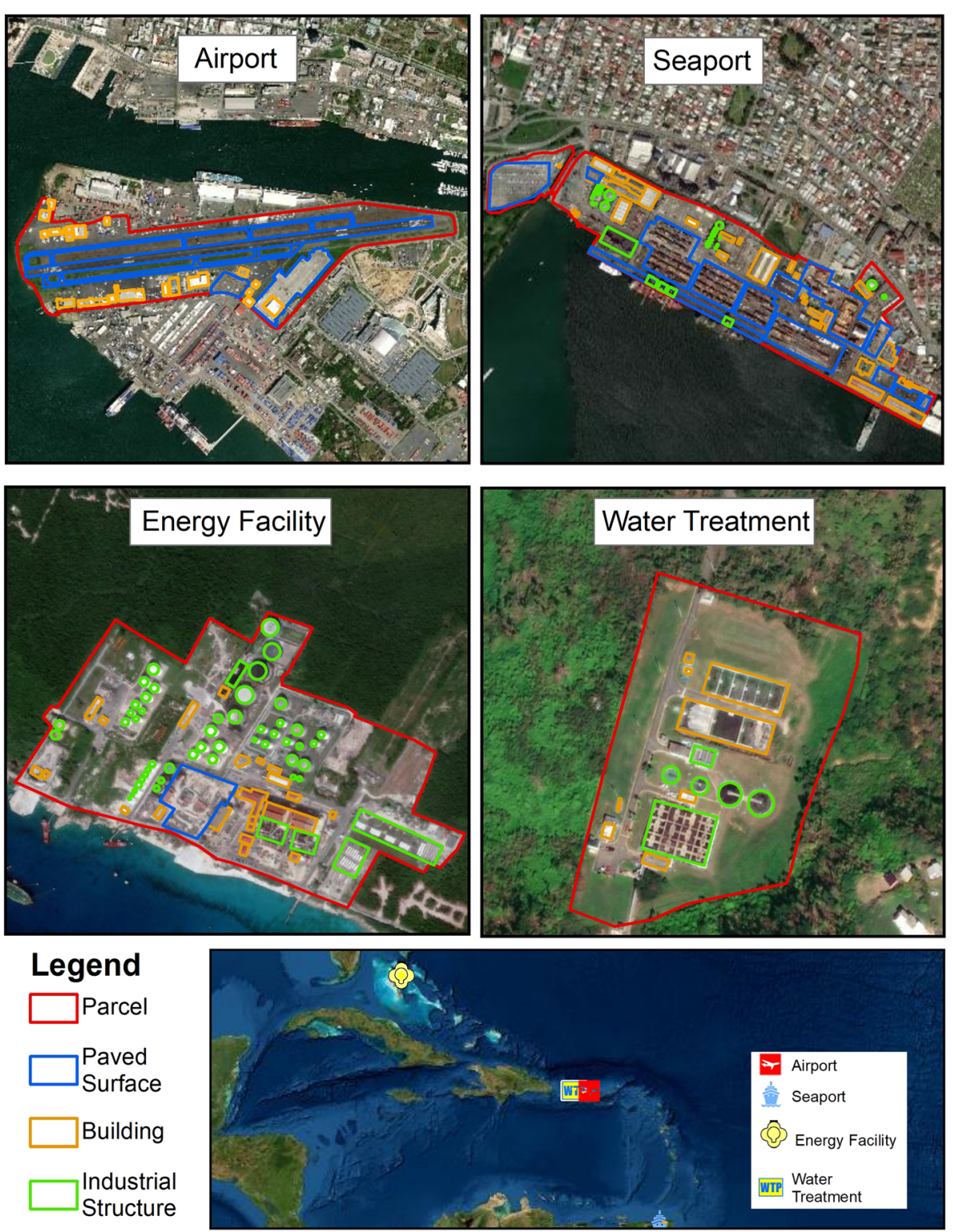

Fig. 3 Example mapped critical infrastructure facilities and key features. a Fernando Luis Ribas Dominicci Airport, Puerto Rico; b Port of Spain, Trinidad and Tobago; c Bahama Light and Power Clifton Pier, The Bahamas; d Planta De Tratamiento De Aguas Negras, Puerto Rico

for pilots. Rising air temperatures and decreasing air density over the coming century will impact airplane takeoff, resulting in the need for longer runways. Increasing heat can buckle pavement, reduce payload limits, and lead to other health and safety risks. Sea level rise and storm surge further threaten airstrips that often extend directly over the sea on filled land [65]. We identified 71 airports in the Caribbean that meet the criteria of coastal critical infrastructure, covering 10,588 ha of land (Table 4). At each airport, we mapped paved surfaces including runways, aprons, taxiways, and parking areas, as well as building, including terminal buildings, hangars, and control towers. An example of a mapped airport is included in Fig. 3a.
Among the critical infrastructure facility types we digitized, airports by far had the largest footprint in the Caribbean in coastal regions. Depending on the size of the airport and the requirements of the planes landing there, runways alone can require a large amount land. For example, the United States Department of Transportation recommends a runways length of $9000 \mathrm{ft}$ for a Boeing 737 [66]. Larger airports may have more than one runway, in addition to taxiways, aprons, and land area dedicated to terminal buildings and parking areas for travelers. Given current climate conditions and the associated need for longer runways, our inventory could be a useful tool to aid planners in designing and 
Table 3 Number of coastal critical infrastructure facilities and total land footprint in the Caribbean

\begin{tabular}{|c|c|c|c|c|c|c|}
\hline \multirow[t]{2}{*}{ Infrastructure Type } & \multirow{2}{*}{$\begin{array}{l}\text { \# of } \\
\text { Facilities } \\
\text { Identified }\end{array}$} & \multirow{2}{*}{$\begin{array}{l}\# \text { of } \\
\text { Facilities } \\
\text { within } 1 \\
\text { km of } \\
\text { Coast }\end{array}$} & \multicolumn{2}{|c|}{ Total footprint (ha.) } & \multicolumn{2}{|c|}{ \# of features mapped } \\
\hline & & & Parcels & Paved Surfaces & Buildings & Tanks \\
\hline Airports & 147 & 71 & 10,589 & 1876 & 671 & N/A \\
\hline Seaports & 210 & 170 & 3704 & 792 & 1494 & 735 \\
\hline Energy Facilities & 136 & 98 & 4619 & 90.5 & 1718 & 2280 \\
\hline Water \& Wastewater Treatment Facilities & 73 & 47 & 206 & 0.3 & 174 & 81 \\
\hline Total & 566 & 386 & 19,118 & 2759.52 & 4057 & 3096 \\
\hline
\end{tabular}

Table 4 Airports results summary

\begin{tabular}{|c|c|c|c|c|c|c|}
\hline \multicolumn{4}{|c|}{ Total footprint (ha.) } & \multicolumn{3}{|c|}{ \# of features mapped } \\
\hline Parcel & Runways & Aprons & Taxiway & Buildings & Terminal Buildings & Hangars \\
\hline $10,588.5$ & 924 & 493 & 411 & 539 & 36 & 87 \\
\hline
\end{tabular}

Table 5 Seaports results summary

\begin{tabular}{|c|c|c|c|c|c|c|c|}
\hline \multirow[t]{2}{*}{ Seaport Type } & \multirow{2}{*}{$\begin{array}{l}\text { \# of } \\
\text { facilities }\end{array}$} & \multicolumn{4}{|c|}{ Total footprint (ha.) } & \multicolumn{2}{|c|}{ \# of features mapped } \\
\hline & & Parcel & Apron & Container Yard & Laydown Area & Buildings & Tanks \\
\hline General Cargo & 101 & 1668.9 & 39.6 & 151.4 & 85.1 & 886 & 322 \\
\hline Container Port & 25 & 1154.1 & 27.8 & 353.7 & 60.5 & 407 & 100 \\
\hline Oil Terminal & 19 & 826.8 & 0.65 & - & 5.5 & 115 & 313 \\
\hline Cruise Port & 25 & 54.5 & 3.4 & - & 2.2 & 86 & - \\
\hline Total & 170 & 3704.3 & 71.5 & 505.1 & 153.1 & 1494 & 735 \\
\hline
\end{tabular}


adapting airports in the coastal regions, where undeveloped land area is already scarce, and will become increasingly scarce with a changing climate.

\section{Seaports}

Seaports serve as the economic lifeblood of island nations, many of which are served by only one seaport which imports all materials and supplies that would be too expensive to transport via air. Island economies depend on cruise ports for tourism, container ports for imports/exports and transshipment, and bulk ports for the import/export of raw materials. Additionally, energy ports import valuable petroleum products needed for road and air transport, as well as general power for the electric grid that powers other critical infrastructure facilities including desalination plants, water treatment plants, and telecommunication systems. Across the 28 island nations in this study, we identified 170 individual seaports, which includes: container ports, cruise ports, oil terminals, and general cargo ports (Table 5). We mapped the full outline of the parcel, the individual buildings, key paved surfaces, and tank used to store petroleum or other liquid products. An example of a mapped seaport is include in Fig. 3b. Results show that 3704 ha of Caribbean land was devoted to seaport infrastructure.

\section{Energy facilities}

Energy facilities play an important role in supplying power to the industries that drive economic growth and development, in addition to powering homes and business. With increased urban development in coastal regions, the placement of energy facilities is critical for supplying power to a growing population. In addition, energy facilities need access to a water source for cooling, with sea water being a common source utilized due to its high availability. For Island nations, reliance on reliable energy infrastructure that supplies consistent power is a vital function for maintaining health and wellbeing among the residents of island nations, as well as ensuring these countries can produce goods and services that can be distributed between islands and the global economy.

In total, we located and mapped 98 energy facilities throughout the Caribbean region, including: fossil fuel power plants, nuclear power plants, oil refineries, solar farms, and wind farms (Table 6). We mapped the facility land area, buildings, structures dedicated to generating power, and tank farms used to store fuel. An example of a mapped energy facility is included in Fig. 3c. In total, energy facilities covered 4619 ha of the coastal land in the Caribbean region. Not surprisingly, as the size of the country and its population increased, so did the number of facilities and land area dedicated to generation of power and the storage of fuels such as oil, petroleum, or natural gas. Of the 98 facilities mapped, only 8 used a renewable fuel source such as solar or wind, with the rest relying on fossil fuel as a primary fuel source to produce power. The reliance on fossil fuel power plants as a primary fuel source may be indictive of a level of reliability and consistent power supply associated with these fuels sources, in addition to supplying large quantities of power with a relatively small footprint on islands with limited land area to produce enough power to supply a growing population and economy.

\section{Water \& Wastewater Treatment Facilities}

Society depends on safe, clean, treated water to prevent disease and maintain health. Properly treated wastewater protects the environment and similarly prevents disease in humans. Many water and wastewater treatment facilities are located in the coastal zone, as they either rely on seawater as a source (e.g., for a desalination plant) or a destination for treated water [15]. Though such facilities are not limited to coastal locations, such locations are often more cost effective, as the low elevation reduces the need for expensive pumping systems. In this study, we identified 47 water treatment, wastewater treatment, and desalination facilities, encompassing 206 ha of coastal land (Table 7). The limited number of water and wastewater treatment facilities inventoried

Table 6 Energy facilities results summary

\begin{tabular}{|c|c|c|c|c|c|c|}
\hline \multirow[t]{2}{*}{ Energy Facility Types } & \multirow{2}{*}{$\begin{array}{l}\text { \# of } \\
\text { facilities }\end{array}$} & \multicolumn{2}{|c|}{ Total footprint (ha.) } & \multicolumn{3}{|c|}{ \# of features mapped } \\
\hline & & Parcel & Paved Surfaces & Buildings & Power Structures & Tanks \\
\hline Fossil Fuel Power Plant & 66 & 1308.1 & 44.0 & 876 & 116 & 594 \\
\hline Nuclear Power Plant & 1 & 15.0 & 1.1 & 15 & 7 & 38 \\
\hline Oil Refinery & 23 & 3155.4 & 45.4 & 824 & 62 & 1658 \\
\hline Solar Farm & 4 & 103.6 & - & 3 & - & - \\
\hline Wind Farm & 4 & 36.9 & - & - & - & - \\
\hline Total & 98 & 4619 & 90.5 & 1718 & 185 & 2280 \\
\hline
\end{tabular}


Table 7 Water and wastewater treatment facilities results summary

\begin{tabular}{|c|c|c|c|c|c|c|}
\hline \multirow{2}{*}{$\begin{array}{l}\text { Water Treatment Facility } \\
\text { Types }\end{array}$} & \multirow{2}{*}{$\begin{array}{l}\text { \# of } \\
\text { facilities }\end{array}$} & \multicolumn{2}{|c|}{ Total footprint (ha.) } & \multicolumn{3}{|c|}{ \# of features mapped } \\
\hline & & Parcel & Paved Surfaces & Buildings & Clarifiers & Tanks \\
\hline Water Treatment Plant & 16 & 55.2 & - & 69 & 21 & 30 \\
\hline Wastewater Treatment Plant & 27 & 119.5 & 0.32 & 77 & 64 & 29 \\
\hline Desalination Plant & 4 & 31.4 & - & 24 & - & 22 \\
\hline Total & 47 & 206.1 & 0.32 & 170 & 85 & 81 \\
\hline
\end{tabular}

may be a result of the lack of a regional database and the challenges of locating these facilities. However, the Caribbean region does suffer for a lack of adequate resources to treat water, with only $17 \%$ of the homes in the region directly connected to a form of water treatment (Fluence News [67]).

\section{Validation exercise/accuracy assessment}

One of the potential applications for this approach is tracking land use over time. For example, researchers could conduct an inventory every five years in order to monitor how infrastructure land use is growing or shrinking for a particular region. To this end, the approach must be replicable such that different individual mappers would make the similar choices with respect to boundaries and classifying assets. To assess the accuracy and replicability of the methodology, we hosted a validation exercise to compare results obtained by independent mappers for a subset of facilities within our database. We recruited 11 volunteer mappers with basic GIS skills. Using a random name generator, two facilities for each facility type (eight facilities in total) were selected for testing. Facilities represented areas from a variety of built-environment densities and had varying resolution satellite imagery. Prior to digitizing the facilities, mappers reviewed our SOP and partook in a two-hour training exercise. Once they reviewed the materials, each mapper was assigned four facilities and tasked with determining and digitizing the parcel boundary, buildings, and other features for each facility. We then compared the percent overlap between polygon boundaries to determine the effectiveness of our methodology in guiding mappers to create a dataset that matched the one created by our research team. In addition, we made comparisons to data derived from OpenStreetMaps (OSM) for the same subset of facilities. However, of the eight facilities selected for the validation exercise, only four were mapped in OSM for comparison.

To determine the percentage of parcel polygon overlap between our dataset and the participants dataset, we applied the Union tool in ArcMap to join the sample polygon features for each mapper with those in the researcher dataset. We then divided the area that intersected by the total area (i.e., intersecting + non-intersecting) of the joined polygons. In comparison of the polygon overlap for parcels, we found that an average of $83.6 \%$ of the polygon area from the volunteer mapper derived dataset overlapped with our polygon parcels (Table 8). After the exercise, we survey the mappers to identify the components that the participants struggled the most with when completing the exercise. The most common challenges of the exercise identified from the feedback was determining the boundary that surrounded a facility, particularly for facilities that were in densely developed areas. Three of the facilities that were mapped were problematic for participants, with variability in the percentage overlap among mappers (Fig. 4). In comparison to OSM, we found an average of $82.8 \%$ overlap of polygon area between our dataset and the facilities mapped in OSM. Analysis shows that the variation may be indicative of the geographic location of the facility, such as facilities in highly developed regions or areas with lower resolution imagery available, as well as the experience level mappers have with GIS and the efficacy of the methodology we have developed. Overall, the results of this exercise suggest that our approach and SOP provide enough instruction such that different mappers could obtain similar results, though additional training would be helpful to boost replicability. This validation exercise lends confidence to the replicability of this method for conducting such geospatial analysis.

Table 8 Results of the validation exercise and comparison with Open Street Maps

\begin{tabular}{llll}
\hline \% Polygon Overlap & & & \\
\hline Dataset & Mean & Range & SD \\
\hline $\begin{array}{l}\text { Validation Exercise } \\
\text { (\# of mappers = 11, \# of facilities = 8) }\end{array}$ & 83.6 & 45.4 & 14.1 \\
OSM (\# of facilities = 4) & 82.8 & 38.1 & 18.1 \\
\hline
\end{tabular}




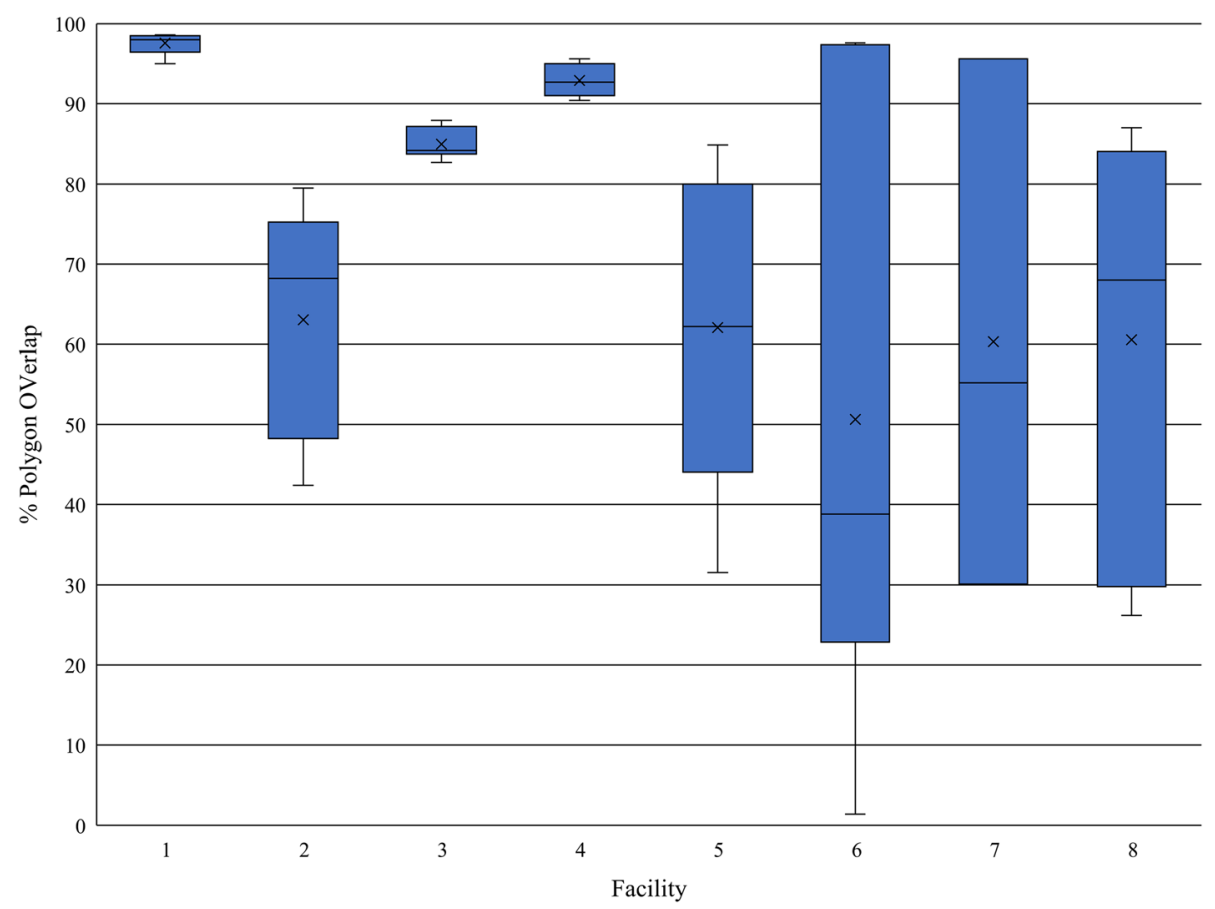

Fig 4 Validation exercise comparison of polygon overlap among eight mappers for each facility type

\section{Discussion and implications}

The primary purpose of this manuscript was to develop a standardized, replicable approach to mapping critical coastal infrastructure using the most-up-to date satellite imagery. The resulting data can be used for a variety of applications. For example, by running a regional sea level analysis, researchers can quantify the amount of critical infrastructure at risk from inundation or storm surge on a more granular level than by simply using point datasets. It could also be used for analysis of other regional trends, such as tracking coastal land utilization over time, regional economic studies, or planning. The approach developed here provides empirical data that has a higher level of precision than estimates based on more generic land use. For example, Dronkers et al. [68] developed an approach to estimate land use for ports based on cargo throughput. This approach was subsequently improved by Hansen and Nicholls [69] for a study that projected 2050 port land use demands based on a variety of economic and climate scenarios. The data resulting from the approach described in this study could allow for validation, as well as for including a wider variety of coastal infrastructure. Additionally, this data could be used to identify facilities and infrastructure storing hazardous materials, such as oil refineries and power stations, that could potentially release pollutants into the surrounding ecosystem similar to what occurred in Galveston Bay during Hurricane Harvey [2].
While the Caribbean was used as a case study for this pilot, there are many other regions throughout the world with finite land area and infrastructure located in lowlying coastal areas. Many will likely experience similar climate related challenges. For example, island nations located in the South Pacific are particularly susceptible to climate related hazards. A recent study on the exposure of infrastructure to climate risks in the South Pacific estimate that $57 \%$ of the infrastructure is located with $500 \mathrm{~m}$ of the coastline [12]. While this study was one of the first to develop a comprehensive assessment of the infrastructure assets vulnerable to climate risk, a point database was used to identify infrastructure, thus limiting the ability to determine the assets at greatest risk. The methodology we outline in this paper provides an opportunity to develop more detailed geodatabases that could be used for a comprehensive analysis of the assets and infrastructure at greatest risk in regions like the South Pacific. While other mapping techniques are available, the SOP standardizes the process of creating spatial data for critical infrastructure features in a way that is cost effective, fast, and useful for projects relying on participatory mapping to generate spatial data. The SOP can also be used as a complimentary guide pre-existing mapping techniques as well as for the creation of geospatial data using OSM or other open source mapping applications. Additionally, the SOP can be utilized to allow for revisions as satellite imagery is updated. 
Next steps for this work include an expansion of the approach to include other types of coastal land use (e.g., marinas and emergency facilities), expanding the SOP to include standardized approaches for mapping other critical infrastructure features, such as roads, bridges, and railways within close proximity to coastal infrastructure facilities, as well as conducting the study in other regions around the world (e.g., the South Pacific). In addition, the data could be used to conduct a regional analysis of Caribbean coastal infrastructure at risk from storm surge, similar to methods described in a pilot study we conducted for the U.S. Virgin Islands [70].

\section{Limitation of this approach}

There are a few challenges and limitations to this approach that warrant discussion. This section describes some of the larger issues.

\section{Identifying facilities}

This manuscript relies on existing point datasets and Google searches to identify where facilities are located along the coast. It then develops those point datasets into polygon datasets to allow for a more nuanced understanding of land use. For ports and airports, we were able to find comprehensive datasets. However, for water treatment and energy facilities, we relied more on Google searches to identify where on each island these facilities could be found. As such, it is possible that some facilities were missed. In next steps, we plan to expand our approach to include other types of uses, such as marinas, hospitals, emergency facilities, and bridges. Some of these, such as marinas, have likely been assembled into databases that can be used to identify locations. Others, however, will rely on a more hands-on approach through Google or other search engines.

\section{Determining parcel boundaries}

"Parcel" generally describes the boundaries of a piece of land held by a particular owner. Delineating such ownership boundaries through an inspection of satellite imagery would be an impossible task. For this project, we consider the parcel to be the land area devoted to a particular infrastructure use. In some cases, identifying this boundary was relatively straightforward, such as for a river or a road. However, in other cases, the mapper needed to use their best judgement to determine where a parcel boundary should be drawn. Though we included several "what if" instructions in the SOP, this type of decision making could lead to errors in the dataset.

\section{Limitations in publicly available imagery}

Acquiring high resolution satellite imagery at the regional scale from a private company could be costly, thus for purposes of this study, we relied on publicly available satellite imagery provided by ESRI. While the cost associated with accessing publicly available data was negligible, a reliance on this imagery presents several limitations as compared to formal imagery sources. For one thing, cloud cover sometimes presented challenges in identifying infrastructure. In addition, the date of the imagery may vary with scale, meaning that as a mapper zooms in on a piece of infrastructure the image date at a higher resolution could be several years earlier or later than that of the image at a smaller scale.

\section{Conclusion}

This paper describes a cost effective, precise and standardized approach to inventory critical infrastructure on a regional scale. Using a heads-up digitizing approach, the methods outlined in this paper can be used to create a high-resolution dataset for the land and key features dedicated to critical infrastructure. The dearth of such datasets has been identified as a barrier to conducting research to understand a variety of issues, especially in developing nations such as many of the islands in the Caribbean. Along with high-resolution bathymetry and elevation data, land use data such as developed in this manuscript is the third major category of data necessary to assess storm surge and sea level rise impacts to the coast at the local and regional scale. Using the 28 islands in the Caribbean region to pilot the approach, we identified 386 critical coastal infrastructure facilities, with over 19,000 ha of coastal land dedicated to critical infrastructure. This data can be available to other researchers who wish to conduct regional-scale work on climate vulnerability or other applications. Such geospatial datasets are necessary for a variety of analyses, including risk assessment and tracking land use change over time for a region. While other approaches to inventorying rely on complex or automated remote sensing or techniques to estimate land use, this approach utilizes satellite imagery and a "standard operating procedure" that guides individual mappers through the process, ensuring replicability and confidence. The approach will be expanded and the SOP further developed to include other regions, such as the South Pacific, and additional types of infrastructure.

\section{Supplementary Information}

The online version contains supplementary material available at https://doi. org/10.1186/s43065-021-00019-0.

\section{Additional file 1.}

\section{Acknowledgements}

The authors of this paper wish to thank the numerous undergraduate and graduate students who contributed to this effort, including Ellis Kalaidjian, Ben Sweeney, Nelle D'Aversa, Alex Sousa, Luis Cruz, Ryan DiPanni, and the volunteer mappers who helped validate the approach. 


\section{Authors' contributions}

$\mathrm{AB}$ and $\mathrm{NH}$ contributed to all aspects of the project, including research design, method development, data collection, analysis, and writing. GB contributed to research design and method development. The authors read and approved the final manuscript.

\section{Funding}

This work was supported by the USDA National Institute of Food and Agriculture, Hatch Regional project 1014166, the Cruise Industry Charitable Foundation, and the University of Rhode Island Research Office.

\section{Availability of data and materials}

The datasets used and/or analyzed during the current study are available from the corresponding author on reasonable request. The data has been made available to view through the University of Rhode Island ArcGIS Online page at https://tinyurl.com/amd746ey.

\section{Declarations}

\section{Competing interests}

The authors declare that they have no competing interests.

\section{Author details}

'Department of Marine Affairs, University of Rhode Island, 1 Greenhouse Rd., Kingston, Rhode Island 02881, USA. ${ }^{2}$ University of the Virgin Islands, 2 John Brewers Bay, St Thomas, V. I. 00802-6004, USA.

\section{Received: 4 February 2021 Accepted: 9 March 2021}

\section{Published online: 07 May 2021}

\section{References}

1. Bernie, C., \& Padgett, J. (2020). Probabilistic assessment of storage tanks subjected to waterborne debris impacts during storm events. doi:https:// doi.org/10.1061/(ASCE)

2. Du J, Park K, Yu X, Zhang YJ, Ye F (2020) Massive pollutants released to Galveston Bay during hurricane Harvey: understanding their retention and pathway using Lagrangian numerical simulations. Sci Total Environ 704: 135364. https://doi.org/10.1016/j.scitotenv.2019.135364

3. Fisher IJ, Phillips PJ, Colella KM, Fisher SC, Tagliaferri T, Foreman WT, Furlong ET (2016) The impact of onsite wastewater disposal systems on groundwater in areas inundated by Hurricane Sandy in New York and New Jersey. Mar Pollut Bull 107(2):509-517. https://doi.org/10.1016/j.marpolbul.2 016.04 .038

4. Fan H, Zipf A, Fu Q, Neis P (2014) Quality assessment for building footprints data on OpenStreetMap. Int J Geogr Inf Sci 28(4):700-719. https://doi.org/1 $0.1080 / 13658816.2013 .867495$

5. Huth J, Kuenzer C, Wehrmann T, Gebhardt S, Tuan VQ, Dech S (2012) Land cover and land use classification with TWOPAC: towards automated processing for pixel- and object-based image classification. Remote Sens 4(9):2530-2553. https://doi.org/10.3390/rs4092530

6. IPCC (Intergovernmental Panel on Climate Change) (2014) Change 2014: impacts, adaptation, and vulnerability. Part B: regional aspects. Contribution of Working Group II to the Fifth Assessment Report of the Intergovernmental Panel on Climate Change. Cambridge University Press, Cambridge, p. 688

7. Cashman, A., \& Nagdee, M. R. (2017). Impacts of climate change on settlements and infrastructure in the coastal and Marine environments of Caribbean Small Island developing states (SIDS). Caribbean marine climate change report card: science review, 157-173

8. Strobl E (2012) The economic growth impact of natural disasters in developing countries: evidence from hurricane strikes in the central American and Caribbean regions. J Dev Econ 97(1):130-141. https://doi. org/10.1016/j.jdeveco.2010.12.002

9. Biondi EL, Guannel G (2018) Practical tools for quantitative analysis of coastal vulnerability and sea level rise impacts_application in a Caribbean island and assessment of the $1.5^{\circ} \mathrm{C}$ threshold. Reg Environ Change. https:// doi.org/10.1007/s10113-018-1397-4

10. Giardino A, Nederhoff K, Vousdoukas M (2018) Coastal hazard risk assessment for small islands: assessing the impact of climate change and disaster reduction measures on Ebeye (Marshall Islands). Reg Environ Chang 18(8):2237-2248. https://doi.org/10.1007/s10113-018-1353-3
11. IPCC (Intergovernmental Panel on Climate Change). (2012). Managing the risks of extreme events and disasters to advance climate change adaptation: special report of the intergovernmental panel on climate change (SREX) (9781139177245). Retrieved from Cambridge: http://ebooks.cambridge.org/ ref/id/CBO9781139177245

12. Kumar L, Taylor S (2015) Exposure of coastal built assets in the South Pacific to climate risks. Nat Clim Chang 5(11):992-996. https://doi.org/10.1038/ nclimate2702

13. Vousdoukas MI, Mentaschi L, Voukouvalas E, Verlaan M, Feyen L (2017) Extreme sea levels on the rise along Europe's coasts. Earth's Future 5(3):304323. https://doi.org/10.1002/2016EF000505

14. de Moel H, Jongman B, Kreibich H, Merz B, Penning-Rowsell E, Ward PJ (2015) Flood risk assessments at different spatial scales. Mitig Adapt Strateg Glob Chang 20(6):865-890. https://doi.org/10.1007/s11027-015-9654-z

15. Hummel MA, Berry MS, Stacey MT (2018) Sea level rise impacts on wastewater treatment systems along the U.S. coasts. Earth's Future 6(4):622633. https://doi.org/10.1002/2017ef000805

16. Pek, S., \& Caldecott, B. (2020). Physical climate-related risks facing airports: an assessment of the world's largest 100 airports briefing paper September 2020. Retrieved from Oxford, UK: https://www.smithschool.ox.ac.uk/research/ sustainable-finance/publications/Physical-climate-risks-facing-airportsbriefing-paper-September-2020.pdf

17. Mirza MMQ (2003) Climate change and extreme weather events: can developing countries adapt? Clim Pol 3(3):233-248. https://doi.org/10.3763/ cpol.2003.0330

18. Tol RS (2018) The economic impacts of climate change. Rev Environ Econ Policy 12(1):4-25. https://doi.org/10.1093/reep/rex027

19. Phiri D, Morgenroth J (2017) Developments in Landsat land cover classification methods: a review. Remote Sens 9(9):967. https://doi.org/10.33 90/rs9090967

20. Viana CM, Girão I, Rocha J (2019) Long-term satellite image time-series for land use/land cover change detection using refined open source data in a rural region. Remote Sens 11(9):1104. https://doi.org/10.3390/ rs11091104

21. Meyer WB, Meyer WB, BL Turner I (1994) Changes in land use and land cover: a global perspective, vol 4. Cambridge University Press, Cambridge

22. Abd El-Kawy O, Rød J, Ismail H, Suliman A (2011) Land use and land cover change detection in the western Nile delta of Egypt using remote sensing data. Appl Geogr 31(2):483-494. https://doi.org/10.1016/j.apgeog.2010.10.012

23. Alphan $H$ (2003) Land-use change and urbanization of Adana, Turkey. Land Degrad Dev 14(6):575-586. https://doi.org/10.1002/ldr.581

24. Spruce J, Bolten J, Mohammed IN, Srinivasan R, Lakshmi V (2020) Mapping land use land cover change in the lower Mekong Basin from 1997 to 2010. Front Environ Sci 8:21. https://doi.org/10.3389/fenvs.2020.00021

25. Fu P, Weng Q (2016) A time series analysis of urbanization induced land use and land cover change and its impact on land surface temperature with Landsat imagery. Remote Sens Environ 175:205-214. https://doi.org/10.101 6/j.rse.2015.12.040

26. Pauleit S, Ennos R, Golding Y (2005) Modeling the environmental impacts of urban land use and land cover change-a study in Merseyside, UK. Landsc Urban Plan 71(2-4):295-310. https://doi.org/10.1016/S0169-2046(04 )00083-0

27. Seto KC, Güneralp B, Hutyra LR (2012) Global forecasts of urban expansion to 2030 and direct impacts on biodiversity and carbon pools. Proc Natl Acad Sci 109(40):16083-16088. https://doi.org/10.1073/pnas.1211658109

28. d'Amour CB, Reitsma F, Baiocchi G, Barthel S, Güneralp B, Erb K-H et al (2017) Future urban land expansion and implications for global croplands. Proc Natl Acad Sci 114(34):8939-8944. https://doi.org/10.1073/pnas.1606036114

29. Seto KC, Shepherd JM (2009) Global urban land-use trends and climate impacts. Curr Opin Environ Sustain 1(1):89-95. https://doi.org/10.1016/j. cosust.2009.07.012

30. Silva R, Martínez ML, Hesp PA, Catalan P, Osorio AF, Martell R, Fossati M, Miot da Silva G, Mariño-Tapia I, Pereira P, Cienguegos R, Klein A, Govaere G (2014) Present and future challenges of coastal Erosion in Latin America. J Coast Res 71:1-16. https://doi.org/10.2112/si71-001.1

31. Huq S, Kovats S, Reid H, Satterthwaite D (2007) Reducing risks to cities from disasters and climate change. SAGE Publications Sage UK, London

32. Benediktsson JA, Pesaresi M, Amason K (2003) Classification and feature extraction for remote sensing images from urban areas based on morphological transformations. IEEE Trans Geosci Remote Sens 41(9):19401949. https://doi.org/10.1109/TGRS.2003.814625 
33. Gamba, P., Dell'Acqua, F., Stasolla, M., Trianni, G., Lisini, G., \& Yang, X. (2011) Limits and challenges of optical high-resolution satellite remote sensing for urban applications. Urban remote sensing: monitoring, synthesis and modeling in the urban environment, 36-47

34. Cai G, Ren H, Yang L, Zhang N, Du M, Wu C (2019) Detailed urban land use land cover classification at the metropolitan scale using a three-layer classification scheme. Sensors 19(14):3120. https://doi.org/10.3390/s19143120

35. Blaschke T, Hay GJ, Kelly M, Lang S, Hofmann P, Addink E et al (2014) Geographic object-based image analysis-towards a new paradigm. ISPRS J Photogramm Remote Sens 87(100):180-191. https://doi.org/10.1016/j. isprsjprs.2013.09.014

36. Chen G, Weng Q, Hay GJ, He Y (2018) Geographic object-based image analysis (GEOBIA): emerging trends and future opportunities. GISci Remote Sens 55(2):159-182. https://doi.org/10.1080/15481603.2018.1426092

37. Myint SW, Gober P, Brazel A, Grossman-Clarke S, Weng Q (2011) Per-pixel vs. object-based classification of urban land cover extraction using high spatial resolution imagery. Remote Sens Environ 115(5):1145-1161. https://doi.org/1 0.1016/j.rse.2010.12.017

38. Huang B, Zhao B, Song Y (2018) Urban land-use mapping using a deep convolutional neural network with high spatial resolution multispectral remote sensing imagery. Remote Sens Environ 214:73-86. https://doi.org/1 0.1016/j.rse.2018.04.050

39. Voltersen M, Berger C, Hese S, Schmullius C (2014) Object-based land cover mapping and comprehensive feature calculation for an automated derivation of urban structure types at block level. Remote Sens Environ 154: 192-201. https://doi.org/10.1016/j.rse.2014.08.024

40. Alshehhi R, Marpu PR, Woon WL, Dalla Mura M (2017) Simultaneous extraction of roads and buildings in remote sensing imagery with convolutional neural networks. ISPRS J Photogramm Remote Sens 130:139_ 149. https://doi.org/10.1016/j.isprsjprs.2017.05.002

41. Flanagin AJ, Metzger MJ (2008) The credibility of volunteered geographic information. GeoJournal 72(3-4):137-148. https://doi.org/10.1007/s10708008-9188-y

42. Johnson BA, lizuka K (2016) Integrating OpenStreetMap crowdsourced data and Landsat time-series imagery for rapid land use/land cover (LULC) mapping: case study of the Laguna de bay area of the Philippines. Appl Geogr 67:140-149. https://doi.org/10.1016/j.apgeog.2015.12.006

43. Grippa T, Georganos S, Zarougui S, Bognounou P, Diboulo E, Forget $Y$, Lennert M, Vanhuysse S, Mboga N, Wolff E (2018) Mapping urban land use at street block level using openstreetmap, remote sensing data, and spatial metrics. ISPRS Int J Geo Inf 7(7):246. https://doi.org/10.3390/ ijgi7070246

44. Brovelli MA, Zamboni G (2018) A new method for the assessment of spatial accuracy and completeness of OpenStreetMap building footprints. ISPRS Int J Geo Inf 7(8):289. https://doi.org/10.3390/ijgi7080289

45. Helbich M, Amelunxen C, Neis P, Zipf A (2012) Comparative spatial analysis of positional accuracy of OpenStreetMap and proprietary geodata. Proc Gl_ Forum 4:24

46. Vitousek S, Barnard PL, Fletcher CH, Frazer N, Erikson L, Storlazzi CD (2017) Doubling of coastal flooding frequency within decades due to sea-level rise. Sci Rep 7(1):1-9

47. Fewtrell TJ, Duncan A, Sampson CC, Neal JC, Bates PD (2011) Benchmarking urban flood models of varying complexity and scale using high resolution terrestrial LiDAR data. Phys Chem Earth Parts A/B/C 36(7-8):281-291. https:// doi.org/10.1016/j.pce.2010.12.011

48. Webster TL, Forbes DL, MacKinnon E, Roberts D (2006) Flood-risk mapping for storm-surge events and sea-level rise using lidar for Southeast New Brunswick. Can J Remote Sens 32(2):194-211. https://doi.org/10.5589/m06-016

49. Coveney S, Fotheringham AS (2011) The impact of DEM data source on prediction of flooding and erosion risk due to sea-level rise. Int J Geogr Inf Sci 25(7):1191-1211. https://doi.org/10.1080/13658816.2010.545064

50. Van de Sande B, Lansen J, Hoyng C (2012) Sensitivity of coastal flood risk assessments to digital elevation models. Water 4(3):568-579. https://doi. org/10.3390/w4030568

51. Cooper HM, Chen Q, Fletcher CH, Barbee MM (2013) Assessing vulnerability due to sea-level rise in Maui, Hawai 'i using LiDAR remote sensing and GIS. Clim Chang 116(3-4):547-563. https://doi.org/10.1007/ s10584-012-0510-9

52. Szlafsztein C, Sterr H (2007) A GIS-based vulnerability assessment of coastal natural hazards, state of Pará, Brazil. J Coast Conserv 11(1):53-66. https://doi. org/10.1007/s11852-007-0003-6
53. Tate C, Frazier T (2013) A GIS methodology to assess exposure of coastal infrastructure to storm surge \& sea-level rise: a case study of Sarasota County, Florida. J Geogr Nat Disasters 1:2167-0587

54. Bhaskaran PK, Nayak S, Bonthu SR, Murty PN, Sen D (2013) Performance and validation of a coupled parallel ADCIRC-SWAN model for THANE cyclone in the bay of Bengal. Environ Fluid Mech 13(6):601-623. https://doi.org/10.1 007/s10652-013-9284-5

55. Dietrich J, Dawson C, Proft J, Howard M, Wells G, Fleming J et al (2013) Real-time forecasting and visualization of hurricane waves and storm surge using SWAN+ ADCIRC and FigureGen. In: Computational challenges in the geosciences. Springer, New York, pp 49-70

56. Neumann B, Vafeidis AT, Zimmermann J, Nicholls RJ (2015) Future coastal population growth and exposure to sea-level rise and coastal flooding-a global assessment. PLoS One 10(3):e0118571. https://doi.org/10.1371/journa l.pone.0118571

57. Becker A, Wilson A, Bannon R, McCann J, Robadue D, Kennedy S (2010) Rhode Island Ports \& Commercial Harbors A GIS-based Inventory of Current Uses and Infrastructure. Rhode Island Statewide Planning Program, Providence, RI. https://www.rigis.org/datasets/ports-and-commercial-harbors

58. Lewsey C, Cid G, Kruse E (2004) Assessing climate change impacts on coastal infrastructure in the Eastern Caribbean. Mar Policy 28(5):393-409. https://doi.org/10.1016/j.marpol.2003.10.016

59. Inter-American Development Bank. (2014). Climate change and IDB: building resilience and reducing emissions; regional study: LAC small island developing states

60. Monioudi IN, Asariotis R, Becker A, Bhat C, Dowding-Gooden D, Esteban M et al (2018) Climate change impacts on critical international transportation assets of Caribbean Small Island Developing States (SIDS): the case of Jamaica and Saint Lucia. Reg Environ Chang 18(8):2211-2225. https://doi. org/10.1007/s10113-018-1360-4

61. DATASET NGA (National Geospatial-Intelligence Agency): World Port Index. (2019). World port index [Shapefile]. Retrieved from: https://msi.nga.mil/ Publications/WPI, Accessed 20 May 2020

62. DATASET World Port Source: Countries with ports in the Caribbean. (2020). Countries with ports in the Caribbean [Shapefile]. Retrieved from: http:// www.worldportsource.com/ports/region.12.php, Accessed 15 May 2020

63. DATASET OpenFlights: OpenFlights Airport Database. (2017). Open flights airport database [Flat File]. Retrieved from: https://openflights.org/data.html, Accessed 20 May 2020

64. DATASET World Airport Database. (2020). World airport database [flat file]. Retrieved from: http//mww.world-airport-database.com/, Accessed 20 May 2020

65. UNCTAD (United Nations Conference on Trade and Development). (2020). Climate Change Impacts and Adaptation for Coastal Transport Infrastructure: A Compilation of Policies and Practices (978-92-1-112970-0). Retrieved from, DOl: https://doi.org/10.18356/224bcf95-en

66. USDOT (United States Department of Transportation). (2005). Runway length requirements for airport design. Retrieved from https://www.faa.gov/ documentLibrary/media/Advisory_Circular/AC_150_5325-4B.pdf

67. Team, F. N. (2018). The Caribbean's wastewater problem. Retrieved from https://www.fluencecorp.com/the-caribbeans-wastewater-problem/

68. Dronkers, J., Gilbert, T., Butler, L., Carey, J., Campbell, J., James, E.,... von Dadelszen, J. (1990). Strategies for adaption to sea level rise. Retrieved from Geneva: http://papers.risingsea.net/federal_reports/IPCC-1990-adaption-tosea-level-rise.pdf

69. Hanson SE, Nicholls RJ (2020) Demand for ports to 2050: climate policy, growing trade and the impacts of sea-level rise. Earth's Future 8(8): e2020EF001543. https://doi.org/10.1029/2020ef001543

70. Bove G, Becker A, Sweeney B, Vousdoukas M, Kulp S (2020) A method for regional estimation of climate change exposure of coastal infrastructure: case of USVI and the influence of digital elevation models on assessments. Sci Total Environ 710:136162. https://doi.org/10.1016/j.scitotenv.2019.136162

\section{Publisher's Note}

Springer Nature remains neutral with regard to jurisdictional claims in published maps and institutional affiliations. 